\title{
Retraction Note: Nuclear factor of activated T cells 5 maintained by Hotair suppression of miR-568 upregulates S100 calcium binding protein A4 to promote breast cancer metastasis
}

\author{
Jun-Tang Li ${ }^{1,2+}$, Li-Feng Wang ${ }^{3+}$, Ya-Li Zhao ${ }^{2+}$, Tao Yang ${ }^{1}$, Wei Li ${ }^{1}$, Jing Zhao ${ }^{3}$, Feng Y ${ }^{2}$, Lei Wang ${ }^{3}$,

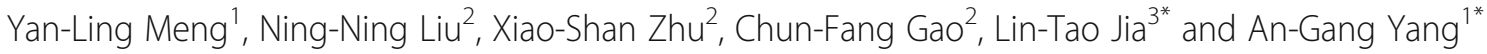

\section{Retraction}

The authors are retracting this article [1] after an investigation by the Ethics Committee of the Fourth Military Medical University (Xi'an, Shaanxi, China) of the following concerns that had been raised with respect to two of the figures:

Figure $1 C$, upper panel: areas of the image labelled as "Mock" and of that shown as "Scramble" are duplicated.

Figure 1D: the image labelled as "Scramble, 24 h" and that shown as "siNFAT5, $48 \mathrm{~h}$ " are duplicated.

Figure 3A: areas of the image labelled as "Invaded, siCtrl" and that shown as "Before Scraping, siS100A4" are duplicated.

All authors agree with this retraction.

\begin{abstract}
Author details
${ }^{1}$ State Key Laboratory of Cancer Biology, Department of Immunology, Fourth Military Medical University, Xi'an 710032, Shaanxi, China. ${ }^{2}$ Institute of Anal-Colorectal Surgery, No. 150 Central Hospital of PLA, Luoyang 471000, Henan, China. ${ }^{3}$ Department of Biochemistry and Molecular Biology, Fourth Military Medical University, Xi'an 710032, Shaanxi, China.
\end{abstract}

Received: 17 July 2018 Accepted: 17 July 2018

Published online: 25 July 2018

\section{Reference}

1. Li J-T, Wang L-F, Zhao Y-L, Yang T, Li W, Zhao J, et al. Nuclear factor of activated T cells 5 maintained by Hotair suppression of miR-568 upregulates S100 calcium binding protein A4 to promote breast cancer metastasis. Breast Cancer Res. 2014;16:454. https://doi.org/10.1186/s13058-014-0454-2.

\footnotetext{
* Correspondence: jialth@fmmu.edu.cn; agyang@fmmu.edu.cn

†Jun-Tang Li, Li-Feng Wang and Ya-Li Zhao contributed equally to this work. ${ }^{3}$ Department of Biochemistry and Molecular Biology, Fourth Military Medical University, Xi'an 710032, Shaanxi, China

'State Key Laboratory of Cancer Biology, Department of Immunology, Fourth Military Medical University, Xi'an 710032, Shaanxi, China

Full list of author information is available at the end of the article
}

(c) The Author(s). 2018 Open Access This article is distributed under the terms of the Creative Commons Attribution 4.0 International License (http://creativecommons.org/licenses/by/4.0/), which permits unrestricted use, distribution, and reproduction in any medium, provided you give appropriate credit to the original author(s) and the source, provide a link to the Creative Commons license, and indicate if changes were made. The Creative Commons Public Domain Dedication waiver (http://creativecommons.org/publicdomain/zero/1.0/) applies to the data made available in this article, unless otherwise stated. 